\title{
Trends in etnocentrische reacties onder de Nederlandse bevolking, 1979-2012
}

Marcel Coenders, Marcel Lubbers, Manfred te Grotenhuis, Paula Thijs \& Peer Scheepers

\author{
MEM 90 (4): 405-433 \\ DOI: 10.5117/MEM2015.3.COEN
}

\begin{abstract}
Summary
Trends in ethnocentric reactions among the Dutch population, 1979-2012

Based upon predictions from 1996 about future trends in ethnocentric reactions in the Netherlands, we investigate the trends in ethnocentric reactions among the general public from 1979 to 2012. We distinguish two forms of ethnocentric reactions: negative attitudes towards ethnic minorities and public support for ethnic discrimination. In line with one of the predictions from 1996, we find an increase in negative attitudes towards ethnic minorities. Although this relates to increasing levels of diversity in the Netherlands, this finding may also reflect a decrease in the social norm that prohibits overt negative stances towards ethnic minorities. With regard to public support for ethnic discrimination, we find no clear upward or downward trend since the mid-nineties. Lower educated and older birth cohorts show stronger ethnocentric reactions. Although there are some indications that those with secondary educational levels and the youngest birth cohorts show stronger ethnocentric reactions over time, there are no significant differences in trends across educational levels and birth cohorts. Changes in ethnocentric reactions are rather robust across different social categories.
\end{abstract}

Keywords: trends, prejudice, discrimination, ethnocentric reactions

\section{$1 \quad$ Inleiding}

In de WRR-publicatie van 1996 (Ganzeboom \& Ultee) werden trends geschetst in verschillende etnocentrische reacties, te weten de steun voor 
etnische discriminatie en etnische distantie, op grond van gegevens die destijds beschikbaar waren. ${ }^{1}$ In die publicatie werd een globaal overzicht geboden van destijds beschikbare theoretische inzichten waaruit vele hypotheses werden afgeleid die werden getoetst met longitudinale data. Daarbij werd geput uit gegevens die waren verzameld in het onderzoeksprogramma Sociaal-Culturele Ontwikkelingen in Nederland, maar toch vooral in het programma van het Sociaal en Cultureel Planbureau, getiteld Culturele Veranderingen (Scheepers, 1996). Beide programma's zijn tot op heden gecontinueerd zodat we de toenmalige trends, die 'slechts' betrekking hadden op de periode 1979-1993 inmiddels kunnen doortrekken tot en met het jaar 2010 of 2011/2012. Beide databestanden zijn bij uitstek geschikt om de voorspellingen uit het WRR-rapport te toetsen.

De trends die in 1996 waren gevonden op basis van gegevens verzameld tot en met 1993, werden in een afsluitende paragraaf gebruikt om voorspellingen te doen over trends in etnocentrische reacties (vooroordelen, steun voor etnische discriminatie en etnische distantie) over het tijdvak 1994 tot 2015. De 'voorspellingen' luidden destijds dat:

1 autochtone Nederlanders (in het algemeen) in de nabije toekomst in toenemende mate etnocentrisch zouden gaan reageren op de komst en aanwezigheid van allochtone nieuwkomers (Scheepers, 1996, p. 291);

2 met name lager opgeleide autochtonen (lo/lbo) sterker etnocentrisch zouden gaan reageren dan de gemiddelde bevolking (ibidem, p. 292);

3 alsook middelbaar opgeleide autochtonen (mavo/mbo) (ibidem, p. 292);

4 maar ook de jongere cohorten zouden sterker etnocentrisch gaan reageren dan de gemiddelde bevolking (ibidem, p. 292).

In deze bijdrage zullen we deze 'voorspellingen' als centrale vraagstellingen behandelen: kloppen deze voorspellingen op grond van de gegevens waarover we nu beschikken?

\section{Theoretische inzichten en hypothesen}

De voorspellingen over trends in etnocentrische reacties die in 1996 werden gedaan waren vooral gebaseerd op de zogenaamde realistisch-conflicttheorie. In het onderstaande gaan we na of en in hoeverre de voorspellingen, die destijds daaruit werden afgeleid, heden ten dage nog plausibel zijn.

Enkele fundamentele proposities van deze theorie zijn gelegd door 
Coser (1956) en kort daarna door Blumer (1958). Zij postuleerden dat binnen elk sociaal systeem een zekere mate van concurrentie plaatsvindt tussen uiteenlopende etnische groepen om schaarse goederen: banen, huizen, status maar ook om culturele respectievelijk religieuze waarden en macht. Deze concurrentie om schaarse goederen en conflicterende culturele waarden en normen vormt de katalysator voor 'vijandelijkheden' tussen diezelfde etnische groepen. Blalock (1967) voegde daar een analytisch onderscheid aan toe dat nadien is overgenomen door Bobo (1988, 1999): hij stelde dat er altijd wel een zekere mate van feitelijke concurrentie om schaarse goederen, op macro-, en/of mesoniveau, plaatsvindt die ook als zodanig, op microniveau, wordt gepercipieerd door leden van etnische groepen, zij het in uiteenlopende mate. Dit laatste idee is uitgewerkt door Olzak (1992) die stelde dat de concurrentie tussen etnische groepen sterker is wanneer leden van uiteenlopende groepen op dezelfde segmenten van de arbeidsmarkt opereren.

Een cruciale assumptie in de theorie is dat individuen zich tot de een of andere groep moeten rekenen, oftewel een onderscheid moeten maken tussen hun eigen groep, de 'in-group', en andere groepen, de 'out-groups'. Inzichten ontleend aan de theorievorming inzake sociale identiteiten (Tajfel, 1981, 1982) kwamen daarom als geroepen. Tajfel heeft in een serie experimenten aangetoond dat individuen zich bij het minste of geringste al tot een groep rekenen ('social categorisation'), zich identificeren met die groep ('social identification') om dan de eigen groep te vergelijken met de andere groepen ('social comparison') en wel op zodanige wijze dat 'positive group distinctiveness' ontstaat: zij nemen bij de leden van de eigen groep vooral, dus op selectieve wijze, positieve kenmerken waar terwijl zij bij leden van de andere groepen vooral negatieve kenmerken waarnemen. Deze mechanismes worden kort aangeduid als sociale (contra-)identificatie (Scheepers, Felling \& Peters, 1990).

Nadien zijn deze inzichten samengevat in de zogenaamde Ethnic Group Conflict Theory: 'intergroup competition, at an individual as well as at a contextual level, may reinforce the mechanisms of social identification and contra-identification, the eventual outcome of which is ethnic exclusionism' (Coenders \& Scheepers, 1998; Scheepers, Gijsberts \& Coenders, 2002). Op het contextuele (macro-, of meso-) niveau gaat het om observeerbare en meetbare 'feitelijke' concurrentie om schaarse goederen (zoals tekorten aan werk en/of huizen) maar ook om conflicterende waarden; op het individuele (micro-)niveau om concurrentie tussen leden van etnische groepen met soortgelijke kenmerken, bijvoorbeeld doordat zij opereren in hetzelfde segment van de arbeidsmarkt, en om ervaren dreiging van eco- 
nomische of culturele aard. De feitelijke concurrentie tussen etnische groepen neemt toe wanneer er meer leden van andere etnische groepen aanwezig zijn, respectievelijk zich vestigen in het land; dan wel doordat de schaarste toeneemt door bijvoorbeeld werkloosheid of krapte op de huizenmarkt; dan wel door de combinatie van een toename van andere etnische groepen bij een gelijktijdige toename van de schaarste op de huizen-, dan wel arbeidsmarkt.

Welnu, de aantallen niet-westerse allochtonen zijn sinds begin jaren negentig opgelopen van 865.697 in 1990 (CBS Statline, 2013) naar 1.997.584 in 2014, oftewel van 5,8 procent naar 11,9 procent (CBS Statline, 2014). De werkloosheid heeft sterk gefluctueerd in de afgelopen decennia, maar is in recente jaren, sinds het uitbreken van de crisis, gestegen naar vijf procent van de autochtone beroepsbevolking en ruim 15 procent van de allochtone beroepsbevolking (Huijnk, 2014). Gegeven de gestegen aanwezigheid van etnische minderheden in ons land in combinatie met de recent toegenomen werkloosheid, verwachten we dat etnocentrische reacties in het algemeen in de afgelopen decennia zijn toegenomen, zeker in de recentere jaren, hetgeen in lijn is met de toenmalige voorspelling (1).

Daarenboven werd destijds uit bovenstaande proposities afgeleid dat etnocentrische reacties in het bijzonder zouden toenemen bij minder geprivilegieerde Nederlanders, die immers soortgelijke kenmerken hebben als etnische minderheden in termen van opleiding, werk en inkomen. Heden ten dage is het nog steeds zo dat de meerderheid van de allochtonen slechts basisonderwijs heeft genoten, maar het onderwijsniveau stijgt wel. Onder etnische minderheden stijgt bovendien het onderwijsniveau aanzienlijk sneller dan onder autochtonen: allochtonen lopen hun onderwijsachterstand dus in, in tegenstelling tot de trends die er in de jaren tachtig waren (Gijsberts \& Iedema, 2012). Feitelijk komen er verhoudingsgewijs niet alleen steeds meer leden van etnische minderheden met een vmbo/mavo diploma van school af, maar ook steeds meer met een mbo/ havo/vwo diploma. Dat impliceert dat de concurrentie om schaarse banen niet meer beperkt is tot die segmenten van de arbeidsmarkt waar vraag is naar lager opgeleiden, maar zich feitelijk ook voltrekt in andere segmenten van de arbeidsmarkt waar vraag is naar middelbaar opgeleiden: ook daar zal zich concurrentie tussen middelbaar opgeleiden van autochtone versus allochtone afkomst afspelen. Gelet op deze trends zouden we inderdaad verwachten dat etnocentrische reacties met name zouden zijn toegenomen onder laag opgeleiden maar ook onder middelbaar opgeleiden, hetgeen in lijn is met de destijds geformuleerde voorspellingen (2) en (3).

Tenslotte werd destijds voorspeld dat etnocentrische reacties met name 
ook bij (kwetsbaardere) jongere cohorten zouden toenemen: zij zouden geconfronteerd worden met de (toegenomen) aanwezigheid van etnische minderheden op de arbeidsmarkt die zij net willen betreden. Feitelijk is het zo dat de werkloosheid onder jongeren (15-24 jarigen) ongeveer 10 procent bedraagt, ongeveer tweemaal zo hoog als onder volwassenen (ouder dan 24 jaar) (Huijnk, 2014). Geconfronteerd met een dergelijke concurrentie, gaan deze jongeren mogelijkerwijs ook in toenemende mate etnocentrische reacties vertonen, hetgeen opnieuw in lijn is met de destijds opgestelde voorspelling (4).

\section{$3 \quad$ Data en meetinstrumenten}

We beschikken over de dataset Culturele Veranderingen, die veelal jaarlijks of tweejaarlijks is verzameld door of in opdracht van het Sociaal en Cultureel Planbureau (1979-1981, 1983, 1985-1987, 1989, 1991-1998, 2000, 2002, 2004, 2006, 2008 en tenslotte 2010). De data zijn gedeponeerd bij DANS voor secundair gebruik. Het gaat om grote steekproeven van de Nederlandse bevolking (steeds ongeveer 2000 respondenten), waarbij individuen op aselecte wijze werden gekozen om de kans op een representatieve steekproef te maximaliseren. ${ }^{2}$ Dat slaagde tot op grote hoogte, alhoewel Gijsberts (1993) constateerde dat er ook sprake was van een lichte ondervertegenwoordiging van jongeren, ongehuwden en mannen. Uit deze data betrekken we de items die destijds aangeduid werden als 'steun voor etnische discriminatie' (Coenders \& Scheepers, 1998; Scheepers, 1996). Respondenten krijgen daarbij concrete situaties op de arbeidsmarkt en woningmarkt voorgelegd waarbij hen gevraagd wordt om een keus te maken voor ofwel een Nederlandse werknemer of Nederlands gezin, dan wel een buitenlandse werknemer of buitenlands gezin. We vermelden de exacte formulering van de items plus de antwoordmogelijkheden en de schaalbaarheid van de items per jaar in appendix A1. We dichotomiseren deze items zodanig dat we respondenten die geen verschil willen maken tussen Nederlanders en buitenlanders samenvoegen met het kleine percentage respondenten dat voorrang wil verlenen aan buitenlandse werknemers of gezinnen. Deze categorie (score o) zetten we af tegen de respondenten die een antwoord geven ten voordele van de Nederlanders respectievelijk ten nadele van de buitenlanders (score 1), hetgeen we kunnen opvatten als steun voor etnische discriminatie. De items blijken door de jaren heen en voor alle jaren samen steeds in hoge mate schaalbaar $(H=0,73)$ en betrouwbaar $(r h o=0,82)($ zie appendix A1). Daarom menen we dat we deze metingen 
door de jaren heen mogen vergelijken om zo de trend inzake voorspelling 1 vast te stellen.

Daarenboven kunnen we putten uit Sociaal-Culturele Ontwikkelingen in Nederland, i.c., een longitudinaal onderzoeksprogramma dat is gestart in 1979 met een grootschalig survey onder aselecte steekproeven van de Nederlandse bevolking en sindsdien gerepliceerd in 1985-1986, 1990-1991, 19951996, 2000-2001, 2005-2006 en tenslotte in 2011-2012. ${ }^{3}$ De data zijn uitvoerig gedocumenteerd en eveneens gedeponeerd voor secundair gebruik (Felling e.a., 1986, 1987; Eisinga e.a., 1992, 1999, 2002, 2012a, 2012b). De data bevatten een aantal Likert-items waarmee grove negatieve attitudes tegenover diverse etnische minderheden in ons land in samenhang met positieve attitudes tegenover de eigen groep op geldige en betrouwbare wijze worden gemeten sinds 1985 (Scheepers e.a., 1990). In appendix A2 rapporteren we de exacte formuleringen van de items alsook de resultaten van factoranalyses op deze set van items in afzonderlijke jaren. Deze items blijken ééndimensioneel schaalbaar te zijn met een goede betrouwbaarheid (Cronbach's alfa $=0,77$ ) en hoge factorladingen hoewel die licht verschillen tussen de jaren. Ook ten aanzien van deze items menen we daarom dat we ze door de jaren heen mogen vergelijken om voorspelling 1 te toetsen.

Voorts hebben we een aantal demografische kenmerken opgenomen om de voorspellingen 2 tot en met 4 te toetsen. We hebben deze kenmerken zoveel mogelijk geharmoniseerd tussen beide databronnen en tussen de jaren waarin de gegevens zijn verzameld. Opleidingsniveau varieert van 'alleen' de lagere school respectievelijk LBO, MULO/MAVO, MBO, HAVO/ VWO, tot $\mathrm{HBO}$ en WO. Kerklidmaatschap betreft het al dan niet lid zijn van de grotere denominaties in ons land. Kerkbezoek onderscheiden we naar frequentie van bezoek. De cohorten hebben we onderling vergelijkbaar gemaakt naar geboortejaren: 1905-1914, 1915-1924, 1925-1934, 1935-1944, 1945-1954, 1955-1964, 1965-1974, 1975-1984, 1985-1994. Hetzelfde geldt tot op zekere hoogte voor de onderscheiden sociaaleconomische posities waarbij we aantekenen dat we met de gegevens uit Sociaal-Culturele Ontwikkelingen in Nederland wat meer differentiatie in werkzame beroepsgroepen op het spoor kunnen komen. Sekse is in beide databronnen identiek gemeten. Urbanisatiegraad hebben we in de analyses met beide databronnen opgenomen maar niet getoond in de tabellen. Provincie kon alleen in SociaalCulturele Ontwikkelingen in Nederland opgenomen worden. 


\section{$4 \quad$ Analyses}

We verrichten eerst analyses op de afzonderlijke items in de beide databestanden om veranderingen op het spoor te komen. Met de gedichotomiseerde items met betrekking tot steun voor etnische discriminatie (uit Culturele Veranderingen) stellen we de trend vast onder de Nederlanders die een of meerdere keren hun steun voor etnische discriminatie uitspreken. De items met betrekking tot grove negatieve attitudes tegenover etnische minderheden (uit Sociaal-Culturele Ontwikkelingen in Nederland) hebben we om redenen van vergelijkbaarheid eveneens gedichotomiseerd om de trend vast te stellen in het aandeel Nederlanders dat een of meerdere keren hun instemming met deze grove vooroordelen uit: dat zijn de mensen die het eens of zeer eens zijn met minimaal één van de voorgelegde Likert-items.

Vervolgens hebben we analyses uitgevoerd om verschillen tussen groepen (op basis van de demografische kenmerken) te onderzoeken. Voor etnische discriminatie maken we gebruik van een logistische-regressieanalyse (met de dichotome afhankelijke variabele 'geen/wel steun voor discriminatie' in Culturele Veranderingen). Voor de analyses van de negatieve attitude tegenover etnische minderheden hebben we de volledige informatie van de schaal gebruikt (met de metrische afhankelijke variabele in Sociaal-Culturele Ontwikkelingen in Nederland) en hebben we lineaire-regressieanalyses uitgevoerd. We hebben dat zodanig gedaan dat de parameters van alle afzonderlijke demografische categorieën de afwijking in etnocentrische reacties weergeven ten opzichte van de gemiddelde score in het desbetreffende jaar (Sweeney \& Ulveling, 1972).

\section{$5 \quad$ Resultaten: globale longitudinale veranderingen (voorspelling 1)}

\subsection{Veranderingen in de steun voor etnische discriminatie}

In figuur 1 is het percentage respondenten weergegeven dat instemt met discriminatie als het gaat om de vraag wie een vrijkomende woning moet krijgen, wie promotie moet krijgen, of wie ontslagen moet worden. De index geeft het percentage aan van respondenten dat in één of meerdere van deze situaties vóór discriminatie is. In deze figuur zijn de fluctuaties door de jaren heen te volgen. 


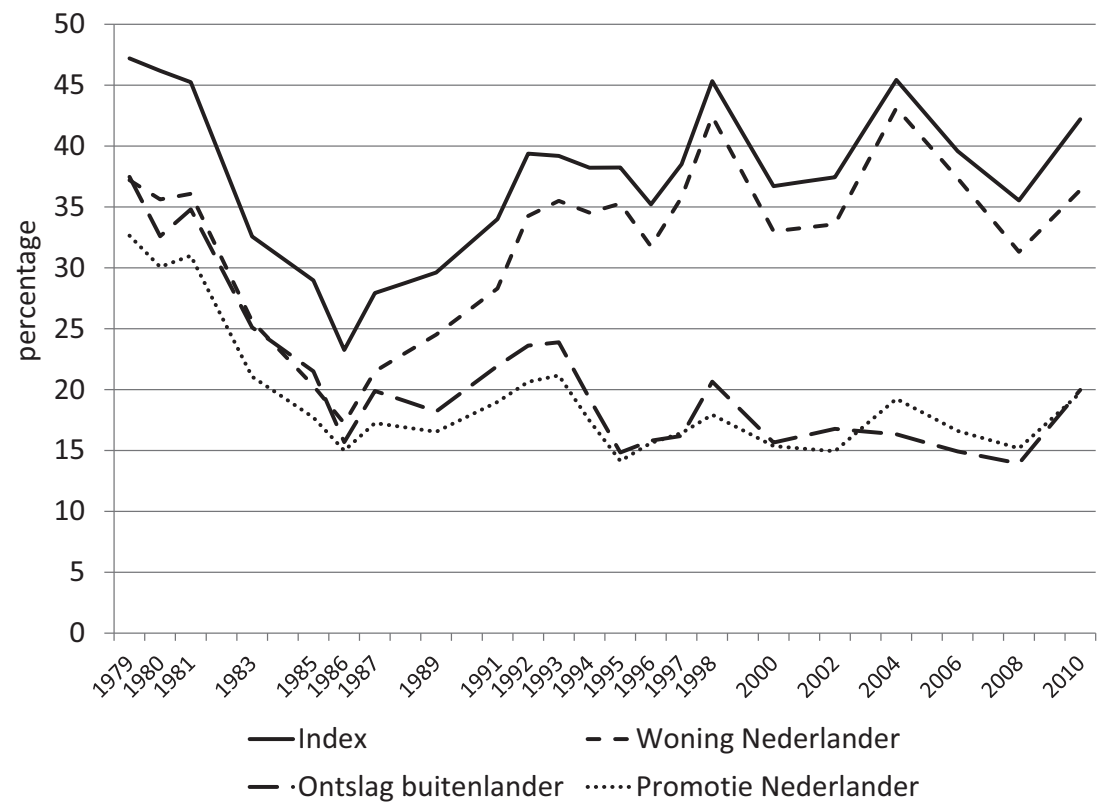

Figuur 1 Trends in de steun voor etnische discriminatie onder de Nederlandse bevolking 1979-2010

Bron: Culturele Veranderingen, 1979-2010

We zien dat de steun voor discriminatie in het begin van de jaren tachtig betrekkelijk wijd verbreid was en werd onderschreven door ongeveer 45 procent van de bevolking. Kort daarna zakte de steun voor discriminatie ineen en halveerde ongeveer: in het midden van de jaren tachtig ondersteunde ongeveer 25 procent van de bevolking discriminatie. In de tweede helft van de jaren tachtig nam de steun voor discriminatie toe naar het niveau van tegen de 40 procent; sindsdien fluctueert de steun voor discriminatie rond dit niveau. Het is opvallend dat de steun voor discriminatie vooral sterk naar voren komt op de huizenmarkt, in ieder geval veel sterker dan op de arbeidsmarkt waar de steun sinds het midden van de jaren negentig consistent fluctueert tussen de 14 en 21 procent.

\subsection{Veranderingen in de negatieve attitude tegenover etnische minderheden}

Vervolgens kijken we naar de trend in de negatieve attitude tegenover etnische minderheden in ons land. We kijken, evenals bij de voorgaande analyse, naar de percentages Nederlanders die het met tenminste één van de negatieve uitspraken over etnische minderheden (helemaal) eens zijn. 


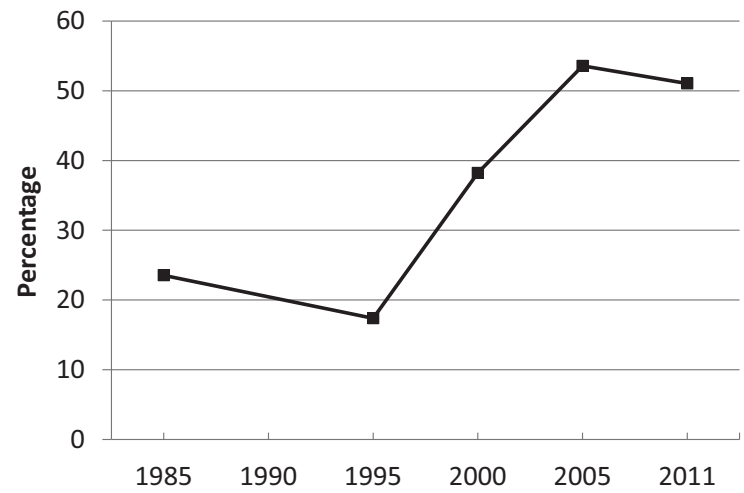

Figuur 2 Trend in de negatieve attitude tegenover etnische minderheden onder

Nederlanders 1985-2011/2012: het percentage respondenten dat instemt met één of meerdere van de voorgelegde stellingen

Bron: Sociaal-Culturele Ontwikkelingen in Nederland, 1985-2011/2012

We zien dat iets minder dan 25 procent van de Nederlandse bevolking in 1985 instemde met tenminste één grove negatieve uitspraak over etnische minderheden. De negatieve houding was dus niet erg wijdverbreid in 1985, hetgeen overeenstemt met de meting van steun voor etnische discriminatie. Tussen 1985 en 1995 is dat percentage zelfs licht gezakt. Maar sindsdien zien we een gestaag oplopende trend: steeds meer Nederlanders onderschrijven de grove negatieve attitude tegenover minderheden in ons land, stijgende naar zo'n 40 procent instemming in 2000-2001 en verder stijgende in 2005-2006; op dat niveau blijft de instemming met deze grove negatieve uitspraken liggen in de jaren 2011-2012: ruim 50 procent van de Nederlanders maakt een grove negatieve houding tegenover etnische minderheden kenbaar.

In het WRR rapport werd voor de periode vanaf het midden van de jaren negentig een globale toename van etnocentrische reacties voorspeld (voorspelling 1). We zien dat er inderdaad sinds 1995 een sterke toename is van een grove negatieve houding tegenover minderheden. De steun voor etnische discriminatie neemt echter sinds het midden van de jaren negentig niet toe. Er zijn sindsdien schommelingen geweest, maar globaal genomen blijft de steun voor etnische discriminatie op een vrij hoog niveau. We vinden dus een gedeeltelijke bevestiging van voorspelling 1: alleen de grove negatieve houding tegenover etnische minderheden is sinds het midden van de jaren negentig sterk toegenomen. 


\section{$6 \quad$ Resultaten: specifieke veranderingen binnen demografische categorieën (voorspellingen 2-4)}

\subsection{Veranderingen in de steun voor etnische discriminatie}

In tabel 1 zijn de resultaten weergegeven van een logistische regressie van de steun voor etnische discriminatie, i.c. indien men in één of meer van de voorgelegde situaties (vrijkomende woning, promotie, ontslag) voorrang geeft aan Nederlanders boven buitenlanders. Het intercept geeft het algemeen gemiddelde weer voor de totale steekproef uit de Nederlandse bevolking. De toe- of afname van het intercept over de jaren heen weerspiegelt dan ook de gemiddelde trend die we hierboven besproken hebben. De andere logistische-regressieparameters geven de mate aan waarin de steun voor etnische discriminatie onder de betreffende bevolkingscategorie hoger of lager is dan gemiddeld onder de Nederlandse bevolking in dat jaar.

Laten we eerst naar de laag opgeleiden kijken: de mensen die alleen lager onderwijs hebben voltooid alsook degenen die een lagere beroepsopleiding hebben genoten. We zien dat de parameter voor de laag opgeleiden in elk jaar significant positief is, hetgeen wil zeggen dat zij in sterkere mate dan de gemiddelde Nederlander steun uitspreken voor etnische discriminatie. Deze parameters lijken ogenschijnlijk ook groter te worden in de latere jaren. Een formele statistische toetsing wijst inderdaad uit dat zulks het geval is: in de latere jaren (vanaf 1989) verschillen de laagst opgeleiden in sterkere mate van de gemiddelde bevolking dan in 1979 (het begin van de tijdreeks, $p<0,05$ ). ${ }^{4}$ Dit is ook te zien in figuur $3 .{ }^{5}$ In deze figuur is op basis van de regressiecoëfficiënten van tabel 1 de verandering weergegeven in steun voor etnische discriminatie onder de gemiddelde bevolking en voor enkele opleidingscategorieën afzonderlijk. We zien in figuur 3 dat in 1979 het verschil tussen lager opgeleiden en de gemiddelde bevolking nog relatief klein is, maar dat dit in de latere jaren groter wordt. Vooral in de periode dat de steun voor discriminatie in Nederland sterk toenam - vanaf midden jaren tachtig tot begin jaren negentig - zien we onder de lager opgeleiden een nog sterkere groei. Met name in de jaren 1996-1998 en 2002 zijn de verschillen tussen de lager opgeleiden en de gemiddelde bevolking groot. Deze divergentie heeft zich echter in de latere jaren niet doorgezet. De voorspellingen van het WRR-rapport hebben betrekking op de periode vanaf 1994. We zien dat de veranderingen onder de lager opgeleiden in deze periode parallel lopen aan de gemiddelde trend. Een formele statistische toetsing wijst dit ook uit: de parameter voor de lager opgeleiden in tabel 1 in 1994 verschilt niet significant van dezelfde parameter in latere jaren. Daarmee is voorspelling (2) weerlegd: lager opgeleiden laten vanaf 1994 eenzelfde trend zien als de gemiddelde bevolking. 
TRENDS IN ETNOCENTRISCHE REACTIES ONDER DE NEDERLANDSE BEVOLKING, 1979-2012

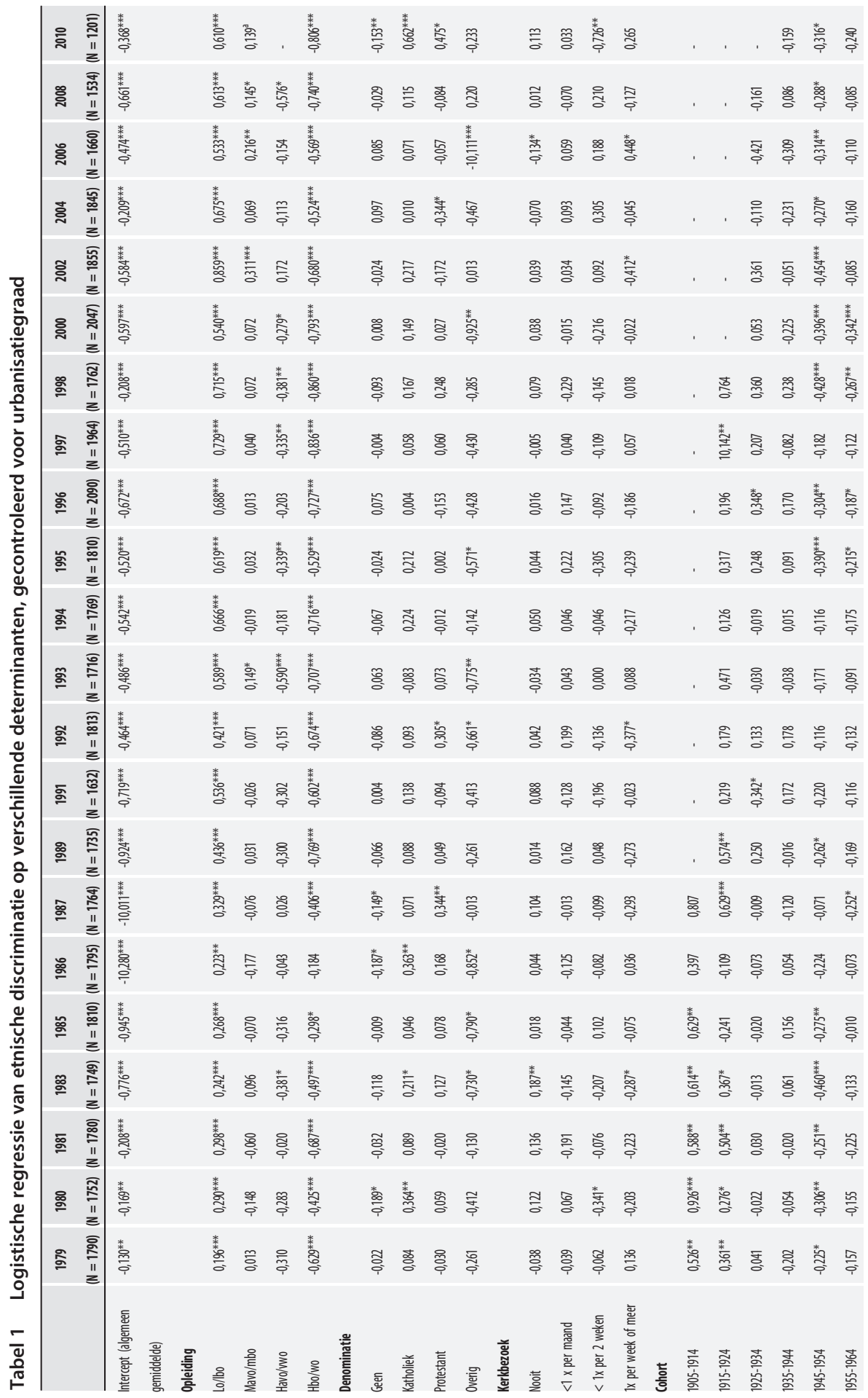


MENS \& MAATSCHAPPIJ

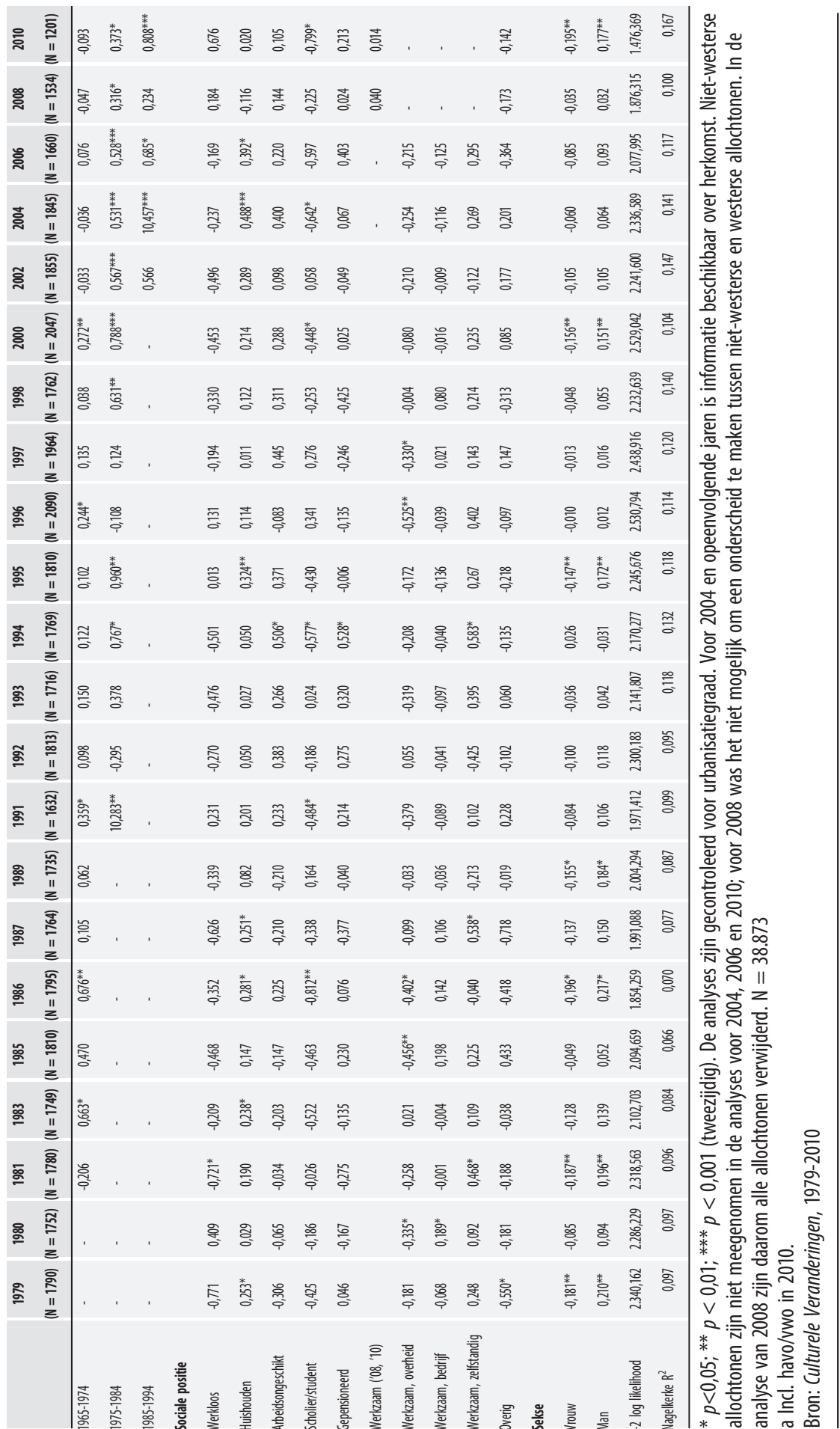




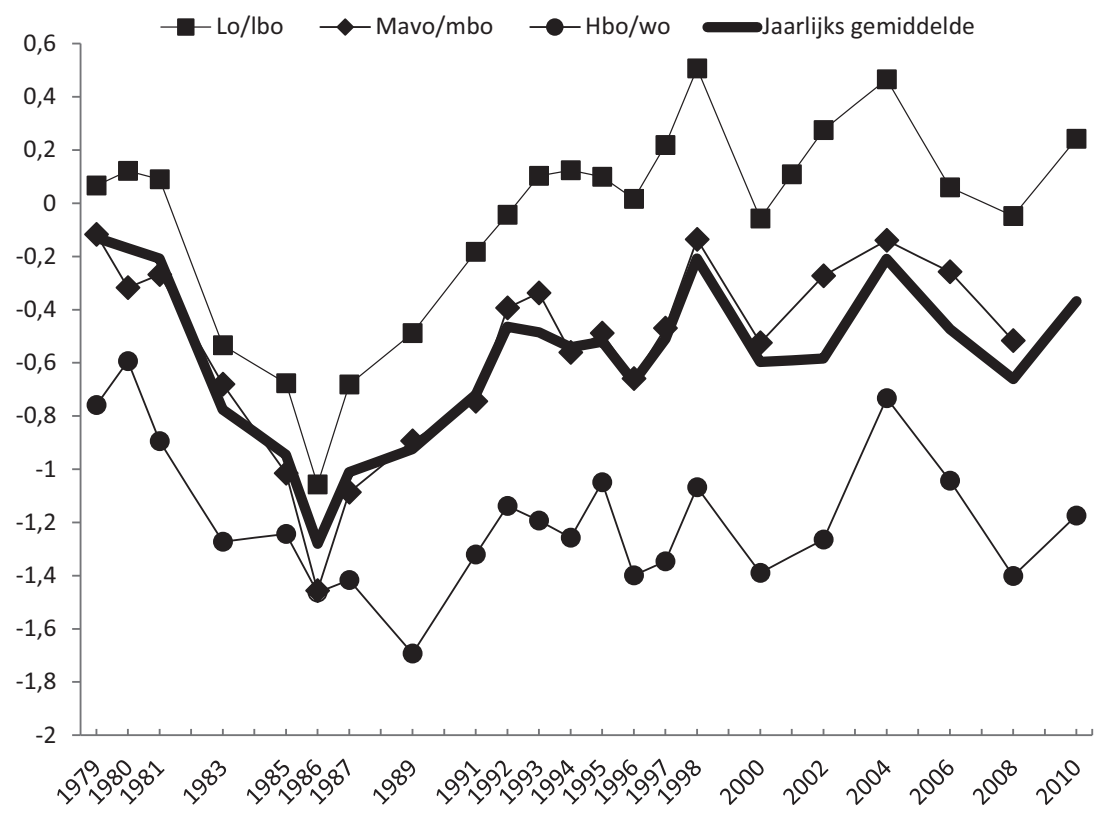

Figuur 3 Steun voor etnische discriminatie: de gecontroleerde log odds (intercept + parameters uit tabel 1) voor lo/lbo, mavo/mbo, en hbo/wo tussen 1979-2010 Bron: Culturele Veranderingen, 1979-2010

Vervolgens kijken we naar de ontwikkelingen onder de mensen die een middelbare opleiding hebben genoten: zij die een mavo- of mbo-diploma op zak hebben. Zij wijken meestal niet af van het algemeen gemiddelde en volgen daarmee de algemene trend. Alleen voor de meeste recente jaren (in 2002, 2006 en 2008) zien we dat zij significant in sterkere mate discriminatie steunen dan gemiddeld, maar dat geldt niet voor 2010. Globaal genomen is er geen sprake van een sterkere groei onder middelbaar opgeleiden en daarmee is ook voorspelling (3) weerlegd. Wellicht ten overvloede vermelden we dat de hoger opgeleiden, zij die havo/vwo-diploma's of hboof universitaire bullen hebben behaald, consistent minder steun uitspreken voor discriminatie dan gemiddeld. Maar ook onder de hoger opgeleiden zien we een vergelijkbare trend als onder de gemiddelde bevolking.

Daarna kijken we naar de veranderingen binnen de cohorten. Dat doen we zonder leeftijd in de modellen op te nemen, omdat dit zou leiden tot zeer ernstige multi-collineariteit. Dit komt omdat in elke afzonderlijke steekproef leeftijd en geboortecohort zeer hoog correleren. De jaarlijkse schattingen voor cohort zijn daarom mogelijkerwijs overschattingen van het 'werkelijke' cohort effect (Te Grotenhuis, Lammers, Pelzer \& Scheepers, 1998). We constateren dat de oudste cohorten, i.c., zij die zijn geboren 
tussen 1905-1914 alsook zij die zijn geboren tussen 1915-1924, in de jaren tachtig overwegend significant positieve parameters hebben: zij vertonen overwegend (1986 uitgezonderd) meer steun voor etnische discriminatie dan de gemiddelde Nederlander. De cohorten geboren tussen 1925-1934 alsook zij die zijn geboren tussen 1935-1944, vertonen slechts in enkele jaren significante parameters, hetgeen wil zeggen dat zij meestal niet van mening verschillen van de gemiddelde Nederlander. De naoorlogse cohorten, zij die geboren zijn tussen 1945-1954 en tussen 1955-1964, kunnen vooral gekenschetst worden met negatieve parameters: zij distantiëren zich in vrijwel alle jaren van de steun voor etnische discriminatie, alhoewel die verschillen niet altijd significant zijn. Echter, onder de jongste cohorten, zij die in of na 1965 zijn geboren, constateren we een duidelijke trendbreuk in vergelijking met de naoorlogse cohorten. Het cohort geboren tussen $1965^{-}$ 1974 vertoont tot en met de eeuwwisseling meer steun voor etnische discriminatie, een ontwikkeling die na de eeuwwisseling is gekeerd: sindsdien zijn de parameters niet meer significant. Ook het cohort geboren tussen 1975-1984 vertoont sinds het begin van de jaren negentig overwegend positieve parameters: mensen geboren in die jaren steunen etnische discriminatie significant meer dan de gemiddelde Nederlander. Deze bevinding geldt eveneens voor het jongste cohort geboren tussen 1985-1994: ook zij spreken sinds de eeuwwisseling, toen zij voor het eerst in de dataverzamelingen voorkwamen, op consistente wijze hun steun uit voor etnische discriminatie.

Hoewel we de cohortparameters 'ongezuiverd' voor leeftijd hebben geschat, lijken zij te wijzen in de richting van cohorteffecten: de steun voor etnische discriminatie lijkt bepaald te worden door ervaringen ten tijde van de formatieve jaren toen de respondenten op een leeftijd waren dat ze de (al dan niet krappe) arbeidsmarkt betraden. Die steun voor discriminatie leeft ook nadien voort, toen zij, naar wij veronderstellen, al beter gesitueerde plaatsen op de arbeidsmarkt hadden veroverd. We vinden de sterkste steun voor etnische discriminatie onder de oudste cohorten. Latere en naoorlogse cohorten vertonen minder steun voor etnische discriminatie, maar de jongste cohorten vertonen juist relatief meer steun voor etnische discriminatie. Als we vervolgens kijken naar de trend per cohort, dan zien we dat alle cohorten globaal eenzelfde trend vertonen als gemiddeld. De jongste cohorten vertonen weliswaar meer steun voor etnische discriminatie dan gemiddeld, maar de veranderingen door de tijd lopen op enkele fluctuaties na - parallel aan de algemene trend. Daarmee is voorspelling (4) weerlegd. In figuur 4 is voor enkele cohorten de trend weergegeven. 


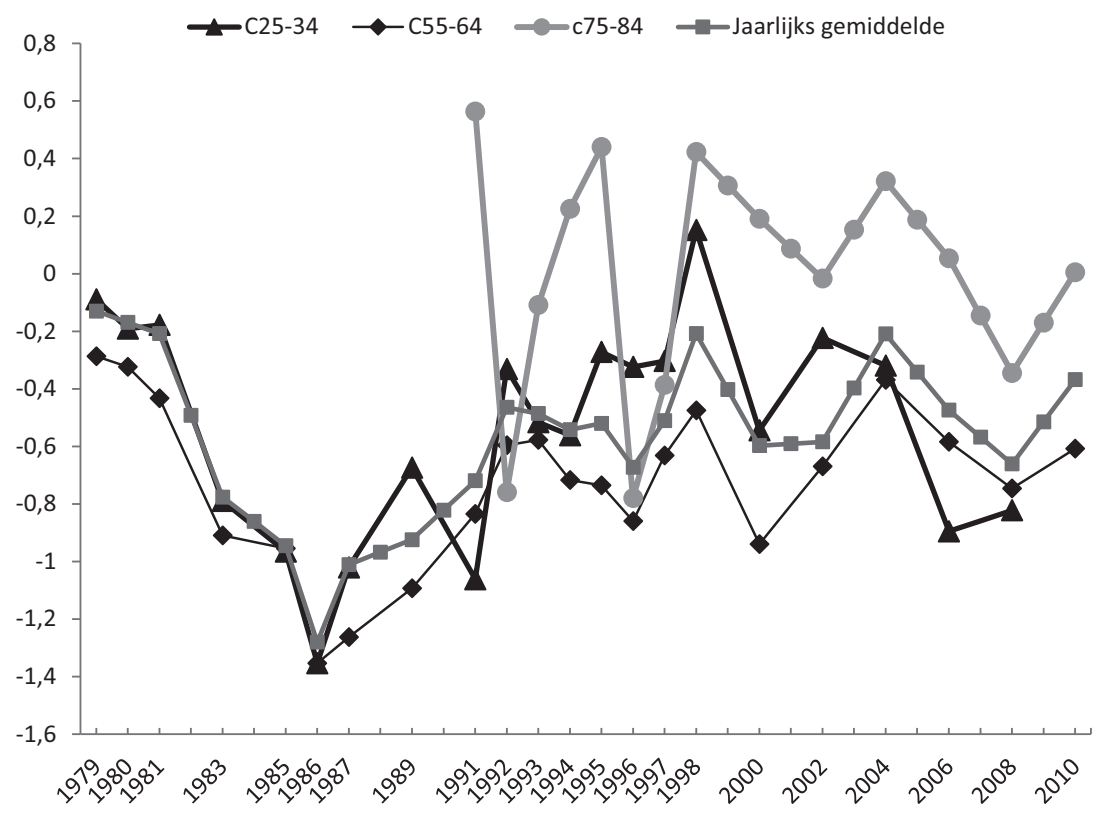

Figuur 4 Steun voor etnische discriminatie: de gecontroleerde log odds (intercept + parameters uit tabel 1) voor de cohorten 1925-34, 1955-64, en 1975-84 tussen 1979-2010

Bron: Culturele Veranderingen, 1979-2010

Tenslotte willen we graag andere patroonmatige bevindingen over het voetlicht brengen, waarover in de WRR-publicatie destijds geen voorspellingen zijn gedaan. Dit betreft in de eerste plaats de standpunten die het katholieke volksdeel heeft ingenomen: zij kennen in enkele jaren positieve parameters (significant in 1980, 1983, 1986, en in 2010) en spreken daarmee hun steun uit voor etnische discriminatie. Voor het protestantse volksdeel geldt dat hun steun nogal heeft gevarieerd in de loop der jaren, soms instemmend, soms afwijzend (in 2004), maar toch spreken ook zij in enkele jaren sterker dan gemiddeld hun steun uit voor etnische discriminatie (significant in 1987, 1992 en 2010). Onkerkelijke Nederlanders, alsook zij die behoren tot de overige kerkgemeenschappen nemen relatief vaker afstand van etnische discriminatie, hetgeen voor de laatste groep sterker en consistenter geldt dan voor de eerstgenoemde groep. We kunnen geen patroonmatige bevindingen vaststellen inzake de mate van kerkgang.

Opmerkelijk mag de positie van de werklozen heten. Gegeven hun kwetsbare positie, zou men wellicht verwachten dat de steun voor discriminatie sterker is onder werklozen dan het gemiddelde. Dat is echter niet het geval: werklozen wijken meestal niet af van de gemiddelde bevolking 
en in een enkel jaar vertonen zij zelfs significant minder steun voor discriminatie dan gemiddeld. De parameters voor werklozen zijn bijna altijd (al dan niet significant) negatief. Alleen in de laatste jaren, sinds het begin van de economische crisis in 2008, zijn de parameters positief en lijken werklozen dus iets meer steun voor discriminatie uit te spreken, maar het verschil is niet significant. Onder scholieren en studenten tenslotte, is de steun voor discriminatie vaker lager.

\subsection{Veranderingen in de negatieve attitude tegenover etnische minderheden}

In tabel 2 zijn de resultaten weergegeven met betrekking tot de negatieve houding tegenover etnische minderheden. Voor de lager opgeleiden vinden we consistent positieve parameters in alle jaren. Zowel de mensen die alleen lagere school hebben gehad alsook de mensen die een LBO-diploma op zak hebben, laten een betrekkelijk sterke negatieve houding tegenover etnische minderheden zien: zij scoren steeds boven het gemiddelde niveau en dat geldt zonder uitzondering voor elk jaar van meting. Een formele statistische toetsing voor de onderlinge verschillen tussen de jaren wijst uit dat de mate waarin de lager opgeleiden afwijken van de gemiddelde bevolking over de jaren heen niet significant verschilt: de paarsgewijze vergelijking tussen de parameters van lager opgeleiden in twee afzonderlijk jaren is telkens niet significant $(p<0,05){ }^{6}$ Daarmee is voorspelling (2) weerlegd: onder lager opgeleiden is de toename in de negatieve houding tegenover etnische minderheden niet sterker dan gemiddeld. In figuur 5 is de algemene trend en de trend voor enkele afzonderlijke opleidingscategorieën afgebeeld. Hierin zien we inderdaad dat de lager opgeleiden weliswaar in elk jaar sterker negatief zijn tegenover etnische minderheden dan gemiddeld, maar dat zij globaal dezelfde trend vertonen als de gemiddelde bevolking. 
Tabel 2 Regressieanalyse van de negatieve houding tegenover minderheden op verschillende determinanten, gecontroleerd voor urbanisatiegraad en provincie (ongestandaardiseerde parameters)

\begin{tabular}{|c|c|c|c|c|c|}
\hline & $\begin{array}{c}1985 \\
(\mathrm{~N}=1527)\end{array}$ & $\begin{array}{c}1995 \\
(\mathrm{~N}=762)\end{array}$ & $\begin{array}{c}2000 \\
(N=795)\end{array}$ & $\begin{array}{c}2005 \\
(N=1088)\end{array}$ & $\begin{array}{c}2011 \\
(\mathrm{~N}=785)\end{array}$ \\
\hline $\begin{array}{l}\text { Intercept (algemeen ge- } \\
\text { middelde) } \\
\text { Opleiding }\end{array}$ & $-0,149^{* * *}$ & $-0,020$ & $-0,016$ & $0,157^{* * *}$ & $0,152^{* * *}$ \\
\hline Lagere school & $0,396^{* * *}$ & $0,311^{* *}$ & $0,316^{* *}$ & $0,406^{* * *}$ & $0,520^{* *}$ \\
\hline LBO & $0,195^{* * *}$ & $0,279 * * *$ & $0,321^{* * *}$ & $0,249^{* * *}$ & $0,250^{* *}$ \\
\hline MULO/MAVO & $-0,025$ & 0,035 & $0,177^{*}$ & $0,151^{*}$ & 0,105 \\
\hline MBO & 0,017 & 0,044 & 0,077 & 0,004 & 0,031 \\
\hline HAVO/VWO & $-0,190^{* *}$ & $-0,180^{*}$ & $-0,194^{*}$ & $-0,017$ & $-0,055$ \\
\hline HBO & $-0,333^{* * *}$ & $-0,223^{* * *}$ & $-0,283^{* * *}$ & $-0,222^{* * *}$ & $-0,142^{*}$ \\
\hline Universiteit & $-0,593^{* * *}$ & $-0,241^{*}$ & $-0,244^{* *}$ & $-0,393^{* * *}$ & $-0,319^{* * *}$ \\
\hline Denominatie $^{a}$ & & & & & \\
\hline Niet-lid & $-0,059$ & $-0,051$ & $-0,056$ & $-0,026$ & $-0,035$ \\
\hline Katholiek & $0,097^{*}$ & 0,109 & 0,122 & 0,075 & $0,224^{* *}$ \\
\hline Protestant & 0,015 & 0,090 & $-0,002$ & $-0,066$ & $-0,106$ \\
\hline Kerkbezoek & & & & & \\
\hline Bijna nooit of nooit & $-0,002$ & $-0,042$ & $-0,009$ & $-0,017$ & $-0,043$ \\
\hline Enkele keren per jaar & $-0,008$ & 0,003 & 0,045 & 0,011 & 0,068 \\
\hline Eenmaal per maand & 0,053 & 0,165 & $-0,040$ & 0,015 & $-0,120$ \\
\hline Eenmaal per week & $-0,014$ & 0,027 & $-0,041$ & 0,048 & 0,133 \\
\hline Cohort & & & & & \\
\hline 1915-1924 & $0,514^{* * *}$ & - & - & - & \\
\hline $1925-1934$ & $0,303^{* * *}$ & $0,352^{* * *}$ & 0,059 & - & - \\
\hline 1935-1944 & $-0,001$ & $0,228^{* *}$ & 0,123 & $0,339^{* * *}$ & 0,196 \\
\hline 1945-1954 & $-0,108^{* *}$ & $-0,011$ & $0,120^{*}$ & 0,008 & 0,063 \\
\hline 1955-1964 & $-0,254^{* * *}$ & $-0,170^{* *}$ & $-0,127^{*}$ & $-0,133^{*}$ & 0,001 \\
\hline $1965-1974$ & $-0,367^{* *}$ & $-0,184^{* *}$ & $-0,126^{*}$ & $-0,216^{* * *}$ & 0,034 \\
\hline $1975-1984$ & - & $-0,146$ & 0,057 & $-0,043$ & $-0,078$ \\
\hline 1985-1993 & - & - & - & 0,020 & $-0,144$ \\
\hline Sociale positie & & & & & \\
\hline Professional & $-0,155^{* *}$ & $-0,095$ & $-0,036$ & $-0,098^{*}$ & $-0,115^{*}$ \\
\hline Witte boorden & $-0,023$ & 0,028 & $-0,071$ & 0,068 & 0,029 \\
\hline Kleine zelfstandigen & $0,299 * *$ & 0,285 & 0,156 & $-0,053$ & 0,260 \\
\hline $\begin{array}{l}\text { Geschoolde handarbei- } \\
\text { ders }\end{array}$ & 0,127 & 0,152 & $-0,044$ & 0,109 & 0,023 \\
\hline $\begin{array}{l}\text { Ongeschoolde handar- } \\
\text { beiders }\end{array}$ & 0,068 & $-0,007$ & $-0,014$ & 0,009 & 0,043 \\
\hline Werklozen & 0,121 & $-0,134$ & $-0,029$ & $0,231^{*}$ & $0,315^{* *}$ \\
\hline Gepensioneerden & $-0,141$ & $-0,040$ & $0,339^{*}$ & $-0,066$ & 0,028 \\
\hline
\end{tabular}




\begin{tabular}{|c|c|c|c|c|c|}
\hline & $\begin{array}{c}\mathbf{1 9 8 5} \\
\mathbf{( N = 1 5 2 7})\end{array}$ & $\begin{array}{c}\mathbf{1 9 9 5} \\
\mathbf{( N = 7 6 2 )}\end{array}$ & $\begin{array}{c}\mathbf{2 0 0 0} \\
\mathbf{( N = 7 9 5 )}\end{array}$ & $\begin{array}{c}\mathbf{2 0 0 5} \\
\mathbf{( N = 1 0 8 8})\end{array}$ & $\begin{array}{c}\mathbf{2 0 1 1} \\
\mathbf{( N = 7 8 5 )}\end{array}$ \\
\hline Huisvrouwen & 0,069 & 0,155 & 0,076 & 0,155 & $-0,091$ \\
\hline $\begin{array}{l}\text { Op school } \\
\text { Anderszins }\end{array}$ & $-0,156$ & $-0,151$ & $-0,396^{*}$ & $-0,310^{*}$ & $-0,200$ \\
\hline $\begin{array}{l}\text { Sekse } \\
\text { Vrouw }\end{array}$ & 0,118 & $-0,035$ & 0,186 & 0,069 & 0,111 \\
\hline Man & & & & & \\
\hline $\mathrm{R}^{2}$ (adjusted) & $-0,005$ & $-0,013$ & $-0,044$ & $-0,058^{*}$ & $-0,062^{*}$ \\
\hline
\end{tabular}

${ }^{*} p<0,05 ;{ }^{* *} p<0,01 ;{ }^{* * *} p<0,001$ (tweezijdig). Effecten zijn simultaan geschat. De analyses zijn gecontroleerd voor urbanisatiegraad en provincie. De analyses zijn uitgevoerd op gepoolde data nadat ontbrekende waarden zijn geïmputeerd. Schattingen zijn afwijkingen van het algemeen gemiddelde van de negatieve houding tegenover minderheden. $\mathrm{N}=4.957$

a We tonen geen parameters voor leden van andere kerkgenootschappen: hun aantallen zijn te gering. Bron: Sociaal-Culturele Ontwikkelingen in Nederland, 1985-2011

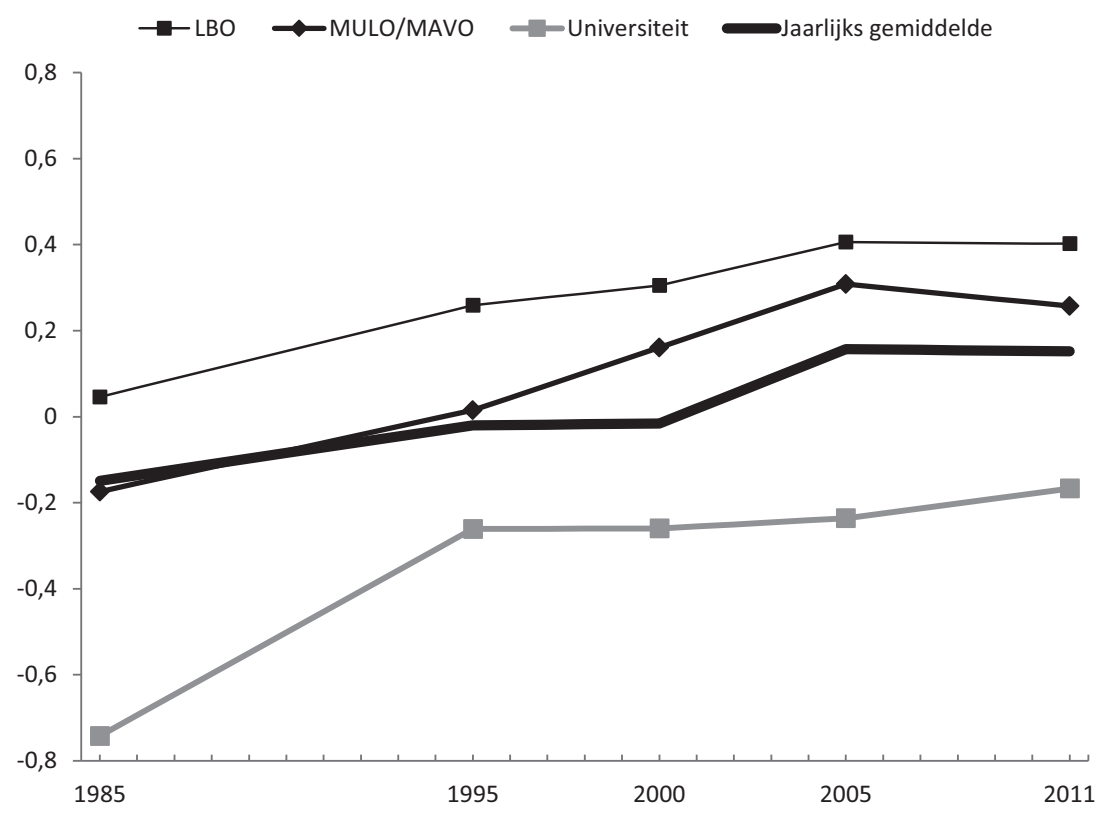

Figuur 5 Negatieve attitude tegenover minderheden: gecontroleerde gemiddeldes (intercept + parameters uit tabel 2) voor lbo, mulo/mavo en universiteit tussen 1985-2011

Bron: Sociaal-Culturele Ontwikkelingen in Nederland, 1985-2011 


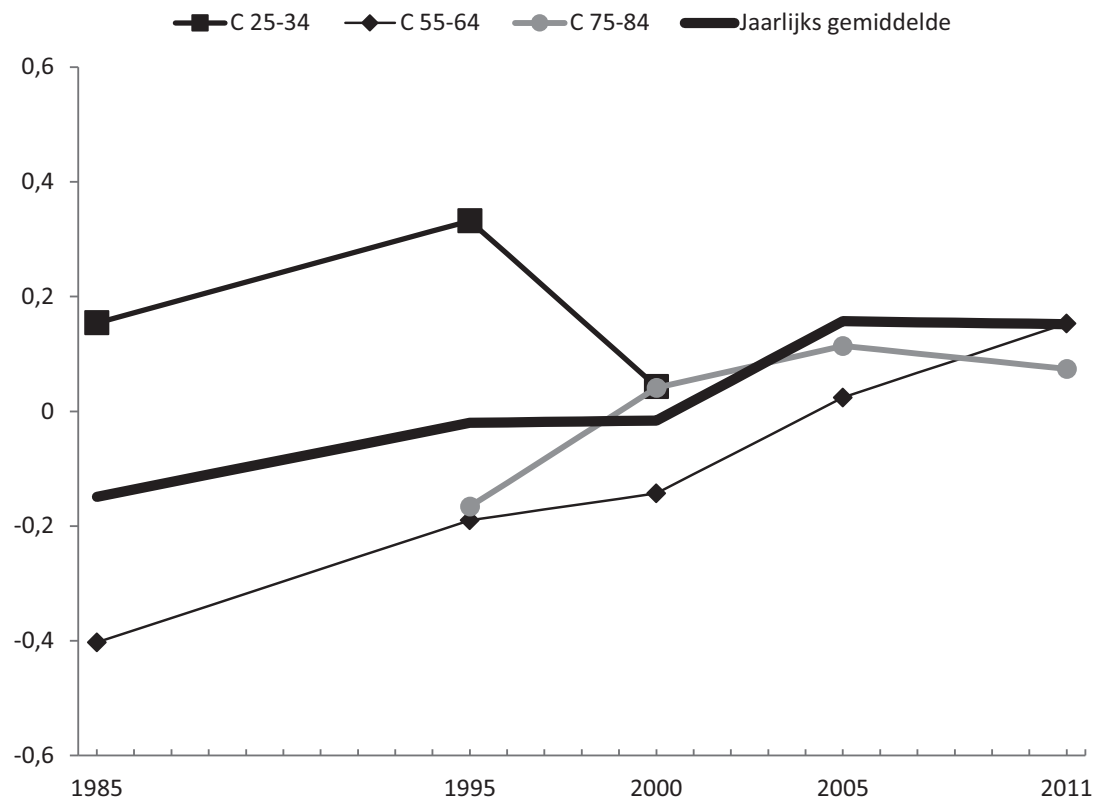

Figuur 6 Negatieve attitude tegenover minderheden: gecontroleerde gemiddeldes (intercept + parameters uit tabel 2) voor de cohorten 1925-34, 1955-64, en 1975-84 tussen 1985-2011

Bron: Sociaal-Culturele Ontwikkelingen in Nederland, 1985-2011

Onder de middelbaar opgeleiden zien we dat de mensen met een MULO/ MAVO-diploma op zak aanvankelijk, in de jaren 1985-1995, niet significant afwijken van de gemiddelde bevolking. In 2000 en 2005 is hun houding echter negatiever dan onder de gemiddelde bevolking. Het lijkt er dus op dat zij in sterkere mate negatiever zijn geworden, maar de verschillen over de jaren heen zijn niet significant. Ook is het verschil ten opzichte van de gemiddelde bevolking in 2011 niet meer significant. Figuur 5 geeft weer dat ook de mensen met een MULO/MAVO-diploma globaal genomen dezelfde trend laten zien als de gemiddelde bevolking. Dit geldt eveneens voor mensen met een MBO-diploma. Ook zij volgen de algemene trend onder de totale bevolking. Tevens geeft tabel 2 aan dat zij in geen enkel jaar significant afwijken van de gemiddelde bevolking. Daarmee is ook voorspelling (3) weerlegd.

Vervolgens kijken we naar de cohorten. Dat doen we wederom zonder leeftijdsverschillen te verdisconteren, waardoor deze verschillen als 'ongezuiverd' moeten worden beschouwd. Ten eerste zien we dat de oudste, vooroorlogse cohorten (1915-1924, 1925-1934, 1935-1944) overwegend posi- 
tieve parameters hebben, hetgeen betekent dat zij een negatievere houding hebben dan gemiddeld. De naoorlogse cohorten (1945-1954, 1955-1964, 1965-1974) kenmerken zich door overwegend negatieve parameters: zij hebben een minder negatieve houding. Maar de jongste cohorten (19751984, 1985-1993) verschillen nooit significant van het algemeen gemiddelde, hetgeen betekent dat zij nabij het gemiddelde niveau van de algemene negatieve houding tegenover minderheden scoren. Dat lijkt - net als bij de steun voor discriminatie - een trendbreuk met de naoorlogse cohorten. Onder de jongste cohorten zien we geen sterkere toename van een negatieve houding dan gemiddeld, zodat we geen bevestiging vinden voor voorspelling (4). In figuur 6 zijn de trends voor enkele afzonderlijke cohorten weergegeven. We zien in elk cohort een toename van de grove negatieve houding tegenover etnische minderheden. Hoewel de in omvang geringere oudste en jongste cohorten wat meer fluctuaties laten zien, is de trend in elk cohort hetzelfde. Wel is er enige mate van convergentie: de verschillen tussen cohorten zijn in 2011 kleiner dan in 1985 .

Andere opmerkelijke en niet voorspelde patroonmatige bevindingen willen we eveneens over het voetlicht brengen. We zien dat de katholieken enkele positieve parameters kennen, hetgeen wil zeggen dat we in dit volksdeel vaker een negatieve houding tegenover minderheden aantreffen, hoewel de verschillen niet in elk jaar significant zijn. De niet-kerkleden wijken niet significant af van de gemiddelde bevolking. Dit is een trend die ook in andere landen zichtbaar is (Scheepers \& Eisinga, 2015). Wat de beroepsgroepen betreft, distantiëren professionals zich relatief vaak van de negatieve houding, terwijl kleine zelfstandigen zich wat negatiever uitlaten over etnische minderheden, hoewel alleen in 1985 het verschil ten opzichte van de gemiddelde bevolking significant is. Scholieren en studenten daarentegen vertonen overwegend een minder negatieve houding tegenover minderheden. Tenslotte onderscheiden werklozen en mannen zich in de decennia voor de eeuwwisseling niet van het algemene gemiddelde, maar sinds 2005 tonen zij een sterkere negatieve houding tegenover minderheden.

\section{$7 \quad$ Conclusie en discussie}

In deze bijdrage hebben we aan de hand van twee grootschalige databestanden de ontwikkeling geschetst voor twee verschillende vormen van etnocentrische reacties: een grove negatieve houding tegenover etnische minderheden en de steun voor etnische discriminatie. Als we de periode 
bekijken dat beide bestanden beschikbaar zijn, de periode van 1985 tot en met 2012, zien we een soortgelijke trend: de etnocentrische reacties van de Nederlanders zijn inderdaad toegenomen. Sinds het midden van de jaren tachtig is het percentage van de Nederlandse bevolking dat steun uitspreekt voor etnische discriminatie van rond de 25 procent in 1985 naar rond de 40 procent in 2010 opgelopen. Voor de grove negatieve houding tegenover minderheden geldt dat die is opgelopen van rond de 25 procent om 1985 naar rond de 50 procent in 2011-2012. Over een lange periode, sinds 1985, zien we dus dat zowel de steun voor etnische discriminatie als de grove negatieve houding tegenover minderheden is toegenomen. Kijken we specifiek naar de periode sinds 1994 - de gegevens die beschikbaar zijn gekomen na het verschijnen van het WRR rapport - dan zien we dat de steun voor etnische discriminatie fluctueert over de jaren heen, maar relatief hoog blijft. Er is sinds het midden van de jaren negentig geen sprake meer van een globale toename in de steun voor etnische discriminatie. De grove negatieve houding tegenover minderheden is daarentegen juist wel sterk toegenomen sinds het midden van de jaren negentig. Daarmee is voorspelling (1) deels uitgekomen: sinds het midden van de jaren negentig is de grove negatieve houding sterk toegenomen. Maar als het gaat om een concreet issue - steun voor discriminatie in specifieke situaties - dan is er geen toename, maar blijft de steun voor discriminatie vrij hoog. In dit verband is het interessant om te speculeren over contextuele determinanten die hebben bijgedragen aan deze hoge mate of zelfs toename van etnocentrische reacties. In eerdere publicaties hebben we op grond van de Ethnic Group Conflict Theory uitdrukkelijk verwezen naar grootschalige demografische veranderingen in de Nederlandse samenleving alsook naar economische fluctuaties (Coenders, Lubbers, Scheepers \& Verkuyten, 2008). Maar evenzeer zou de merkbare verruwing inzake het benoemen van integratieproblemen die via de media van vooraanstaande opiniemakers en politici naar de Nederlandse bevolking toekomt in deze van belang kunnen zijn (Scheffer, 2007).

We achten het met name opmerkelijk dat de trend in de grove negatieve houding tegenover minderheden zo sterk is opgelopen: het gaat in deze meting immers om grove uitspraken, 'die u ook wel eens gehoord zult hebben op de markt of in de kroeg', die door steeds meer Nederlanders openlijk worden onderschreven. Daarmee openbaart zich, als het ware, een sterke onderstroom in de Nederlandse samenleving: het eens zo sterke taboe dat er rustte op negatieve uitspraken over de aanwezige of aankomende etnische minderheden is voor een (groot) deel van de bevolking irrelevant of een anachronisme geworden. Vele Nederlanders betuigen hun 
steun aan dergelijke 'rauwe' vooroordelen, zoals die destijds in het begin van de jaren tachtig van de vorige eeuw werden geconceptualiseerd door Hagendoorn en Janssen (1983; Scheepers et al., 1990) en destijds nog voorpaginanieuws vormden van landelijke dagbladen. Wij 'vrezen' dat zulks niet meer het geval is, ondanks de verruimde mogelijkheden die Nederlanders hebben gekregen om in contact te treden met minderheden in ons land. Er bestaat overtuigende evidentie dat interetnische contacten de mate van vooroordelen reduceren (Pettigrew \& Tropp, 2006). Dergelijke contactmogelijkheden, waarvan geldige indicatoren over een lange periode niet beschikbaar zijn in landelijke surveys, hebben de trend van de grove negatieve houding tegenover minderheden echter niet kunnen keren.

In eerdere publicaties toonden we eveneens aan dat een dergelijke onderstroom niet alleen naar voren komt in deze grove negatieve houding tegenover etnische minderheden, maar eveneens in de mate dat Nederlanders zich bedreigd voelen door dezelfde minderheden, autoritaristische reacties vertonen en hun politieke cynisme uiten (Lubbers, Scheepers \& Jaspers, 2010). Deze groeiende onderstroom loopt gezamenlijk, als het ware, over in een grote vijver waarin met name ver-rechtse politieke partijen kunnen vissen naar electoraal gewin, hetgeen in toenemende mate gelukt is.

Wat betreft de mate van etnocentrische reacties onder lager en hoger opgeleiden, zien we in elk jaar robuuste verschillen. Onder lager opgeleiden is de steun voor etnische discriminatie en een grove negatieve houding sterker aanwezig dan onder hoger opgeleiden. Deze bevinding is in lijn met de robuuste en cross-nationale evidentie die er bestaat voor de relatie tussen opleiding en allerlei aspecten van etnocentrisme (Vogt, 1997; Coenders \& Scheepers, 2003). Deze bevinding is ook goed te begrijpen vanuit de Ethnic Group Conflict Theory: lager opgeleiden moeten op de arbeidsmarkt relatief meer concurreren met etnische minderheden.

Met betrekking tot de veranderingen over de tijd constateren we echter dat er geen evidentie is dat er onder lager opgeleiden een sterkere toename is geweest van etnocentrische reacties. Alleen in de periode dat de steun voor etnische discriminatie in Nederland sterk toenam - vanaf midden jaren tachtig tot begin jaren negentig - zien we dat de steun voor etnische discriminatie onder lager opgeleiden nog sterker groeide. Maar deze relatieve groei heeft zich daarna niet doorgezet. De voorspellingen uit het WRR rapport hebben betrekking op de periode vanaf 1994. Hier zien we dat de veranderingen in de steun voor discriminatie en de negatieve houding onder lager opgeleiden globaal eenzelfde patroon volgen als onder de gemiddelde bevolking. Dat geldt ook voor de veranderingen onder andere 
opleidingscategorieën, zoals middelbaar opgeleiden: hoewel zij zich in enkele jaren na de eeuwwisseling sterker uitspreken voor etnische discriminatie, is dat weer afgenomen in 2010. Complementair aan deze trends is de robuuste bevinding dat hoger opgeleiden zich consistent distantiëren van etnocentrische reacties. Op grond van de civilisatietheorie van Elias (1939) had wellicht afgeleid kunnen worden dat de positie van deze hoger opgeleiden, gepaard gaande met de invloed die er van hen uit zou kunnen gaan, tot een beschavingsoffensief zou hebben geleid: net zoals de voormalige elites hun etiquette als gedragsnormen op het gewone volk hebben overgebracht, kunnen hoger opgeleiden hun afwijzing van etnocentrische reacties op de lager opgeleiden overbrengen. Maar dit is overduidelijk niet gebeurd in de afgelopen decennia.

Voor de verschillen tussen cohorten in de mate van etnocentrische reacties kwamen we tot betrekkelijk eenduidige bevindingen, weliswaar met de kanttekening dat deze bevindingen 'slechts' indicatief zijn, want ze zijn ongezuiverd voor periode- en leeftijdskenmerken. De patroonmatige bevindingen zijn dat we onder de oudste cohorten, geboren vóór 1944, relatief meer steun vinden voor discriminatie en een sterkere grove negatieve houding tegenover minderheden. De naoorlogse cohorten, geboren tussen 1945 en 1964, daarentegen, distantiëren zich nadrukkelijk daarvan. De stellingnames van het cohort geboren tussen 1965-1974 vormen het begin van een trendbreuk met de hun voorgegane cohorten: zij spreken tot de eeuwwisseling juist hun steun uit voor etnische discriminatie en verschillen nadien niet meer significant van de gemiddelde Nederlander. De trendbreuk wordt verder zichtbaar in de jongste cohorten, geboren na 1975, die zich duidelijker uitspreken voor etnische discriminatie. Op dit punt willen we opmerken dat deze ontwikkelingen duidelijker waarneembaar zijn met betrekking tot de steun voor etnische discriminatie (in Culturele Veranderingen) dan met betrekking tot de grove negatieve attitude tegenover minderheden (in Sociaal-Culturele Ontwikkelingen in Nederland), terwijl de andere trendmatige bevindingen in beide databronnen waarneembaar zijn. Bij de jongste cohorten is het proces van de-taboeïsering dus het duidelijkst zichtbaar en consistent aanwezig. Maar hun stellingname valt eveneens te begrijpen: deze cohorten werden in hun formatieve jaren geconfronteerd met de toestroom en aanwezigheid van etnische minderheden met wie zij wellicht meenden te moeten concurreren om allerlei, in toenemende mate schaarse goederen. Het valt natuurlijk niet uit te sluiten dat hun harde stellingname in de loop van de jaren, wanneer zij zich in veiligere maatschappelijke posities hebben gemanoeuvreerd, zal veranderen naar een mildere positie. Ondanks de verschillen in de mate 
van etnocentrische reacties, zien we voor elk van de verschillende cohorten nagenoeg dezelfde trend. Alleen voor de negatieve houding tegenover etnische minderheden lijkt er sprake te zijn van convergentie en worden de verschillen tussen de cohorten kleiner.

In deze bijdrage hebben we de voorspellingen van het WRR-rapport over veranderingen in etnocentrische reacties getoetst. Terwijl de steun voor discriminatie in specifieke situaties op de woning- of arbeidsmarkt sinds 1995 niet eenduidig is toe- of afgenomen, maar op eenzelfde hoog niveau continueert, is de grove negatieve houding tegenover etnische minderheden in Nederland sterk toegenomen. Het lijkt erop dat de sociale norm om zich niet negatief te uiten over minderheden sterk is afgenomen, zelfs onder hoger opgeleiden. De bevinding dat de toename in negatieve houding zich zowel onder jong en oud als onder hoog en laag opgeleiden voordoet, duidt erop dat vele segmenten van de samenleving meedeinen op de golven van de tijdgeest.

\section{Noten}

1. We spreken in deze bijdrage niet van etnocentrisme omdat die term verwijst naar een negatieve houding tegenover minderheden en een positieve houding tegenover de eigen groep (vergelijk Scheepers e.a., 1990). Die laatste component is destijds niet in de beschouwing opgenomen en daarover zijn destijds ook geen uitspraken gedaan.

2. Tot en met 1986 werd de steekproef van Culturele Veranderingen getrokken onder 16tot en met 74-jarigen, daarna werden ook oudere respondenten benaderd. Omwille van de vergelijkbaarheid hebben we in elke steekproef alleen de 16- $\mathrm{t} / \mathrm{m}$ 74-jarigen meegenomen. Vanaf 2004 bevat elk databestand van Culturele Veranderingen informatie over de etnische herkomst van respondenten. We hebben daarom vanaf 2004 niet-westerse allochtonen niet in de analyses opgenomen. Voor 2008 was het niet mogelijk om een onderscheid te maken tussen westerse en niet-westerse allochtonen en daarom hebben we in 2008 allochtonen niet in de analyses opgenomen. Omdat er voor de periode vóór 2004 geen informatie over herkomst beschikbaar was, is een onbekend, maar gering aantal respondenten in de steekproeven van 1979 t/m 2002 van niet-westerse allochtone afkomst. Naar verwachting gaat het om enkele procenten. Ter vergelijking, in 2004 vormde niet-westerse allochtonen vier procent van de oorspronkelijke steekproef, in 2010 was dat zes procent.

3. Omwille van de vergelijkbaarheid door de tijd zijn telkens alleen respondenten van 18 tot 70 jaar meegenomen in de analyses. Om dezelfde reden zijn respondenten van allochtone afkomst niet meegenomen in de analyses.

4. We hebben voor elk jaar getoetst of de regressiecoëfficiënt van de betreffende opleidingscategorie significant afwijkt van de betreffende coëfficiënt in 1979. Uit deze toets voor het verschil tussen twee regressiecoëfficiënten (Paternoster, Brame, Mazerolle \& Piquero, 1998) bleek dat vanaf 1989 de regressiecoëfficiënt van de laagst opgeleiden significant groter was dan in 1979. De laagst opgeleiden wijken in de latere jaren dus 
significant sterker af van de gemiddelde bevolking dan in 1979. Voor de andere opleidingscategorieën vonden we nauwelijks significante verschillen ten opzichte van 1979.

5. Om redenen van overzichtelijkheid presenteren we in deze en de volgende figuren niet alle onderscheiden categorieën, maar enkel de opvallende ontwikkelingen waarover we hypothesen hebben.

6. Dit is getoetst met een post-hoc Bonferoni test die uitwijst dat de verschillen tussen de jaren niet significant zijn $(\mathrm{p}<0,05)$.

\section{Referenties}

Blalock, H.M. (1967). Toward a theory of minority group relations. New York: John Wiley and Sons. Blumer, H. (1958). Race prejudice as a sense of group position. Pacific Sociological Review, 1, 3-7.

Bobo, L. (1988). Group conflict, prejudice, and the paradox of contemporary racial attitudes. In Ph. Katz, \& D. Taylor (Red.), Eliminating racism. Profiles in controversy (pp 85-114). New York: Plenum Press.

Bobo, L. (1999). Prejudice as group position: Microfoundations of a sociological approach to racism and race relations. Journal of Social Issues, 55, 445-472.

CBS Statline (2013). Allochtonen; geslacht, leeftijd en herkomstgroepering, 1 januari. (http://statline.cbs.nl/Statweb/publication/?DM $=$ SLNL\&PA $=70787$ ned $\& D_{1}=0 \& D_{2}=a \& D_{3}=0 \& D_{4}=0-$ $\left.1 \& \mathrm{D}_{5}=18 \& \mathrm{HDR}=\mathrm{T}, \mathrm{G}_{4} \& \mathrm{STB}=\mathrm{G} 1, \mathrm{G}_{2}, \mathrm{G}_{3} \& \mathrm{VW}=\mathrm{T}\right)$.

CBS Statline (2014). Bevolking; generatie, geslacht, leeftijd en herkomstgroepering, 1 januari. (http://statline.cbs.nl/Statweb/publication/?DM=SLNL\&PA=37325\&$\left.\mathrm{D}_{1}=\mathrm{a} \& \mathrm{D}_{2}=0 \& \mathrm{D}_{3}=0 \& \mathrm{D}_{4}=0 \& \mathrm{D}_{5}=3 \& \mathrm{D} 6=\mathrm{l} \& \mathrm{HDR}=\mathrm{T} \& \mathrm{STB}=\mathrm{G}_{1}, \mathrm{G}_{2}, \mathrm{G}_{3}, \mathrm{G}_{4}, \mathrm{G}_{5} \& \mathrm{VW}=\mathrm{T}\right)$.

Coenders, M. \& Scheepers, P. (1998). Support for ethnic discrimination in the Netherlands 19791993: Effects of period, cohort, and individual differences. European Sociological Review, 14, 405-422.

Coenders, M. \& Scheepers, P. (2003). The effect of education on nationalism and ethnic exclusionism, an international comparison. Political Psychology, 24, 313-343.

Coenders, M., Lubbers, M., Scheepers, P. \& Verkuyten, M. (2008). Two decades of changing ethnic attitudes in the Netherlands. Journal of Social Issues, 64, 269-285.

Coser, L. (1956). The functions of social conflict. Glencoe, Ill.: The Free Press.

Eisinga, R., Felling, A., Peters, J., Scheepers, P. \& Schreuder, O. (1992). Religion in Dutch society 90. Documentation of a national survey on religious and secular attitudes in 1990. Amsterdam: Steinmetz Archive.

Eisinga, R., Felling, A., Peters, J. \& Scheepers, P. (1999). Religion in Dutch society 95. Documentation of a national survey on religious and secular attitudes in 1995. Amsterdam: Steinmetz Archive.

Eisinga, R., Coenders, M., Felling, A., Te Grotenhuis, M., Oomens, S. \& Scheepers, P. (2002). Religion in Dutch society 200o. Documentation of a national survey on religious and secular attitudes in 200o. Amsterdam: Steinmetz Archive.

Eisinga, R., Need, A., Coenders, M., De Graaf, N.D., Lubbers, M. \& Scheepers, P. (2012). Religion in Dutch society 2005-2006. Documentation of a national survey on religious and secular attitudes in 2005-2006. Amsterdam: Amsterdam University Press.

Eisinga, R., Kraaykamp, G., Scheepers, P. \& Thijs, P. (2012). Religion in Dutch society 2011-2012. Documentation of a national survey on religious and secular attitudes in 2011-2012. Amsterdam: Amsterdam University Press.

Elias, N. (1939). Über den Prozess der Zivilisation. Band 2: Wandlungen der Gesellschaft: Entwurf zu einer Theorie der Zivilisation. Basel: Verlag Haus zum Falken. 
Felling, A., Peters, J., Schreuder, O., Eisinga, R. \& Scheepers, P. (1987). Religion in Dutch society 85. Documentation of a national survey on religious and secular attitudes in 1985. Amsterdam: Steinmetz Archive.

Felling, A., Peters, J., Schreuder, O., Scheepers, P. \& Snippenburg, L.B. van (1986). Religion in Dutch society. Documentation of a national survey on religious and secular attitudes in 1979. Amsterdam: Steinmetz Archive.

Ganzeboom, H.G.B. \& Ultee, W. (Red.) (1996). De sociale segmentatie van Nederland in 2015. Den Haag: Sdu Uitgevers.

Gijsberts, M. (1993). Culturele veranderingen: Het wegen waard? Rijswijk: Sociaal en Cultureel Planbureau.

Gijsberts, M. \& Iedema, J. (2012). Opleidingsniveau van niet-schoolgaanden en leerprestaties in het basisonderwijs. In M. Gijsberts, W. Huijnk, \& J. Dagevos (Red.), Jaarrapport integratie 2011 (pp. 76-101). Den Haag: Sociaal en Cultureel Planbureau.

Hagendoorn, L. \& Janssen, J. (1983). Rechtsomkeer. Baarn: Ambo.

Huijnk, W. (2014). De arbeidsmarktpositie in beeld. In W. Huijnk, M. Gijsberts, \& J. Dagevos (Red.), Jaarrapport integratie 2013 (pp. 35-64). Den Haag: Sociaal en Cultureel Planbureau.

Lubbers, M., Scheepers, P. \& Jaspers, E. (2010). De dynamiek in het ver rechtse electoraat rond en om de eeuwwisseling. Migranten Studies, 25, 237-259.

Olzak, S. (1992). The dynamics of ethnic competition and conflict. Stanford: Stanford University Press.

Paternoster, R., Brame, R., Mazerolle, P. \& Piquero, A. (1998). Using the correct statistical test for the equality of regression coefficients. Criminology, 36, 859-866.

Pettigrew, T.F. \& Tropp, L.R. (2006). A meta-analytic test of intergroup contact theory. Journal of Personality and Social Psychology, 9o, 751-783.

Scheffer, P. (2007). Het land van aankomst. Amsterdam: De Bezige Bij.

Scheepers P., Felling, A. \& Peters, J. (1990). Social conditions, authoritarianism and ethnocentrism; A theoretical model of the early Frankfurt School updated and tested. European Sociological Review, 6, 15-29.

Scheepers, P. (1996). Etnocentrisme en rechts-extremisme, reacties op de komst en aanwezigheid van etnische minderheden. In H. Ganzeboom, \& W. Ultee (Red.), De sociale segmentatie van Nederland in 2015 (pp. 247-302). Den Haag: Sdu Uitgevers.

Scheepers, P., Gijsberts, M. \& Coenders, M. (2002). Ethnic exclusionism in European countries: Public opposition to grant civil rights to legal migrants as a response to perceived ethnic threat. European Sociological Review, 18, 17-34.

Scheepers, P. \& Eisinga, R. (2015). Religion and intolerance. In J.D. Wright (Ed.), International encyclopedia for the social and behavioral sciences (pp. 381-383). Amsterdam: Elsevier.

Sweeney, R.E. \& Ulveling, E.F. (1972). A transformation for simplifying the interpretation of coefficients of binary variables in regression analysis. The American Statistician, 26, 30-32.

Tajfel, H. (1981). Human groups and social categories: Studies in social psychology. Cambridge: Cambridge University Press.

Tajfel, H. (1982). Social psychology of intergroup relations. Annual Review of Psychology, 33, 1-39.

Te Grotenhuis, M., Lammers, J., Pelzer, B. \& Scheepers, P. (1998). De (on-) mogelijkheid om het leeftijds-, periode-, en cohorteffect te bepalen: Een evaluatie aan de hand van het kerkbezoek in Nederland tussen 1970 en 1995. Sociologische Gids, 45, 8-28.

Vogt, P.W. (1997). Tolerance and education; Learning to live with diversity and difference. Thousand Oaks, CA: Sage. 


\section{Over de auteurs}

Marcel Coenders is universitair hoofddocent bij de afdeling Culturele Diversiteit en Jeugd, Faculteit Sociale Wetenschappen van de Universiteit Utrecht. Zijn onderzoek richt zich op interetnische verhoudingen, solidariteit, vooroordelen en discriminatie op de arbeidsmarkt.

Correspondentieadres: Universiteit Utrecht, afdeling Culturele Diversiteit en Jeugd, Padualaan 14, 3584 CH Utrecht.

E-mail: m.coenders@uu.nl

Marcel Lubbers is universitair hoofddocent bij de sectie Sociologie van de Radboud Universiteit Nijmegen. Zijn onderzoek richt zich op rechts radicalisme, euroscepsis, interetnische relaties en integratie van migranten. Postadres: Sectie Sociologie, Radboud Universiteit, Postbus 9104, 6500 HE Nijmegen

Manfred te Grotenhuis is universitair docent kwantitatieve analysetechnieken bij de sectie Sociologie van de Radboud Universiteit Nijmegen. Zijn onderzoeksbelangstelling gaat uit naar toepassingen van regressieanalyse, meerniveau-analyse en tegenfeitelijkheidsanalyse.

Postadres: Sectie Sociologie, Radboud Universiteit, Postbus 9104, 6500 HE Nijmegen

Paula Thijs is als promovenda verbonden aan het ICS en de sectie Sociologie van de Radboud Universiteit Nijmegen. Haar onderzoek richt zich op veranderingen in sociaal-politieke houdingen in westerse landen en de bijdrage van onderwijsexpansie en ontkerkelijking aan deze veranderingen.

Postadres: Sectie Sociologie, Radboud Universiteit, Postbus 9104, 6500 HE Nijmegen

Peer Scheepers is hoogleraar methodologie en vice-decaan van de Faculteit Sociale Wetenschappen van de Radboud Universiteit te Nijmegen en lid van de Koninklijke Academie van Wetenschappen. Hij heeft veel studies gepubliceerd over vraagstukken inzake sociale cohesie en modernisering in zeer uiteenlopende internationale tijdschriften op het gebied van sociologie, politicologie en psychologie.

Postadres: Sectie Sociologie, Radboud Universiteit, Postbus 9104, 6500 HE Nijmegen 


\section{Appendix A1 Resultaten van de Mokkenanalyses}

1 Ik ga u nu steeds twee verschillende soorten gezinnen of personen oplezen. Wij zouden graag van u willen weten wie van de twee volgens $\mathrm{u}$ tijdens een periode van woningschaarste een vrijkomende woning zou moeten krijgen. 1. Gezin van een gastarbeider [vanaf 2004: gezin van een buitenlander]. 2. Nederlands gezin. 3. Mag geen verschil maken (deze antwoordoptie wordt niet door de interviewer voorgelezen).

2 Veronderstel dat er twee werknemers zijn, die op één punt verschillen, maar overigens op alle andere punten gelijk zijn. Als één van hen ontslagen moet worden omdat het met het bedrijf slecht gaat, wie zou dat volgens u dan moeten zijn? 1. Een buitenlander. 2. Een Nederlander. 3. Mag geen verschil maken (deze antwoordoptie wordt niet door de interviewer voorgelezen).

3 Veronderstel dat er twee werknemers zijn, die op één punt verschillen, maar overigens op alle andere punten gelijk zijn. Als maar één van beiden in aanmerking kan komen voor promotie, wie zou het dan moeten zijn? 1. Een buitenlander. 2. Een Nederlander. 3. Mag geen verschil maken (deze antwoordoptie wordt niet door de interviewer voorgelezen).

Schaalbaarheidscoëfficiënt $(\mathrm{H})$ en betrouwbaarheid (rho) per jaar

\begin{tabular}{ll|l|l}
\hline jaar & H & Rho & N \\
\hline 1979 & 0,70 & 0,85 & 1841 \\
1980 & 0,64 & 0,81 & 1782 \\
1981 & 0,71 & 0,86 & 1810 \\
1983 & 0,75 & 0,88 & 1780 \\
1985 & 0,66 & 0,83 & 1846 \\
1986 & 0,68 & 0,84 & 1875 \\
1987 & 0,72 & 0,86 & 1790 \\
1989 & 0,74 & 0,84 & 1779 \\
1991 & 0,73 & 0,83 & 1664 \\
1992 & 0,75 & 0,83 & 1871 \\
1993 & 0,81 & 0,85 & 1763 \\
1994 & 0,77 & 0,82 & 1821 \\
1995 & 0,73 & 0,77 & 1888 \\
1996 & 0,74 & 0,80 & 2119 \\
1997 & 0,76 & 0,81 & 1989 \\
1998 & 0,76 & 0,79 & 1767 \\
2000 & 0,74 & 0,79 & 2051 \\
2002 & 0,73 & 0,77 & 1861 \\
\hline
\end{tabular}




\begin{tabular}{l|l|l|l}
\hline jaar & H & Rho & N \\
\hline 2004 & 0,72 & 0,79 & 1855 \\
2006 & 0,74 & 0,80 & 1662 \\
2008 & 0,66 & 0,76 & 1542 \\
2010 & 0,68 & 0,78 & 1201 \\
Alle jaren & 0,73 & 0,82 & 39557 \\
\hline
\end{tabular}

Bron: Culturele Veranderingen 1979-2010

\section{Appendix A2 Resultaten van factoranalyses}

Factorladingen, Eigenwaarden en verklaarde variantie per jaar en in totaal

\begin{tabular}{|c|c|c|c|c|c|c|}
\hline & $\begin{array}{c}1985 \\
(\mathrm{~N}=1606)\end{array}$ & $\begin{array}{c}1995 \\
(\mathrm{~N}=779)\end{array}$ & $\begin{array}{c}2000 \\
(\mathrm{~N}=811)\end{array}$ & $\begin{array}{c}2005 \\
(\mathrm{~N}=1144)\end{array}$ & $\begin{array}{c}2011 \\
N=805)\end{array}$ & $\begin{array}{c}\text { Totaal } \\
(\mathrm{N}=5145)\end{array}$ \\
\hline $\begin{array}{l}\text { Met Marokkanen weet je } \\
\text { nooit zeker of ze niet } \\
\text { agressief worden }\end{array}$ & 0,731 & 0,713 & 0,681 & 0,647 & 0,624 & 0,675 \\
\hline $\begin{array}{l}\text { De meeste Surinamers } \\
\text { werken nogal langzaam }\end{array}$ & 0,691 & 0,503 & 0,616 & 0,565 & 0,596 & 0,606 \\
\hline $\begin{array}{l}\text { Zigeuners zijn nooit te } \\
\text { vertrouwen }\end{array}$ & 0,757 & 0,753 & 0,754 & 0,657 & 0,650 & 0,715 \\
\hline $\begin{array}{l}\text { Turken hebben zoveel } \\
\text { kinderen omdat ze nog niet } \\
\text { beter weten }\end{array}$ & 0,602 & 0,425 & 0,589 & 0,463 & 0,587 & 0,519 \\
\hline $\begin{array}{l}\text { Als je met Joden zaken } \\
\text { doet moet je extra oppas- } \\
\text { sen }\end{array}$ & 0,706 & 0,616 & 0,655 & 0,622 & 0,610 & 0,669 \\
\hline Eigenwaarde & 2,949 & 2,465 & 2,741 & 2,402 & 2,506 & 2,832 \\
\hline Verklaarde variantie & $58,9 \%$ & $49,3 \%$ & $54,8 \%$ & $48,0 \%$ & $50,1 \%$ & $52,5 \%$ \\
\hline
\end{tabular}

Bron: Sociaal-Culturele Ontwikkelingen in Nederland, 1985-2011 
